\title{
Interaction of economically useful traits in cows of different breeds
}

\author{
M.B. Rebezov ${ }^{1}$, A.S. Gorelik ${ }^{2, *}$, Y.S. Pavlova ${ }^{1}$, E.V. Khorobrykh ${ }^{1}$, and P.V. Sharavyev ${ }^{1}$ \\ ${ }^{1}$ Ural State Agricultural University, 42 Karl Liebknecht str., 620075 Yekaterinburg, Russian \\ Federation \\ ${ }^{2}$ Ural Institute of the State Fire Service of the EMERCOM of Russia, 22 Mira str., 620062 \\ Yekaterinburg, Russian Federation
}

\begin{abstract}
A related Holstein breed has recently been used to improve domestic dairy cattle and create highly productive herds by purchasing semen from breeding bulls, as well as a large number of heifers and calves of foreign breeding. The purpose of the work is a comparative assessment of the productive qualities of Black Pied and Holstein cows of foreign breeding. Purebred Holstein cows differ from animals of Black Pied breed in milk yield per lactation. Cows of both breeds have fairly high suitability for machine milking. The priority remains with the animals of the Holstein breed of foreign selection. In terms of milking intensity and udder volume, they reliably surpass Black Pied cows at $\mathrm{P} \leq 0.05-\mathrm{P} \leq 0.01$, respectively, in terms of indicators. Holstein cows were also the best in the udder index. Correlation coefficients between the productive qualities, as well as between the quantitative indicator of productivity and the qualitative indicators of the suitability of cows for machine milking, were the same or did not differ significantly. A positive correlation was established between milk yield and the duration of the service period from 0.1 to 0.05 , depending on the breed.
\end{abstract}

\section{Introduction}

Sustainable supply of the population with high-quality food, including milk, is the main necessity in ensuring the health of the nation and food security of any country [1-7]. Particular attention is paid to the development of dairy farming, since the main quantity of a valuable food product and raw material for the dairy industry, milk, is obtained from cattle, more than $99 \%$ of the total production. An increase in the productivity of cows is inseparably associated with an improvement in the quality of milk [8-18]. The main livestock of dairy cattle belongs to the Russian Black Pied breed, which has separate offsprings, differing in economic and biological characteristics. A related Holstein breed has recently been used to improve the Russian dairy cattle and create highly productive herds by purchasing semen from breeding bulls, a large number of heifers and calves of foreign breeding. The widespread, long-term use of the valuable gene pool of foreign

${ }^{*}$ Corresponding author: olgao205en@yandex.ru 
breeding Holstein bulls led to the creation of a large array of Holstein cattle in various climatic and ecological forage zones of the country, which also differs in economically useful and biological characteristics, which is due to the breed resources of cattle breeding zone and country of origin of seed bulls involved in crossing [19-21]. Purebred animals of the Holstein breed were used both for crossing with bulls of the Russian Black Pied breed, and were bred among "themselves" to obtain offspring adapted to local conditions [22-27]. A comparative study of the productive qualities of the Russian Black Pied cattle and Holstein animals of foreign selection is relevant and of practical importance.

The purpose of the work is to study the relationship of economically useful traits of Black Pied and Holstein cows of foreign breeding.

\section{Materials and method}

The studies were carried out in an agricultural enterprise in the Chelyabinsk Region. Two groups of cows with the third lactation were selected for the research, taking into account the date of birth, date of calving, breed characteristics. The first group were cows of the Russian Black Pied breed, the second - Holstein cows of foreign breeding. Milk productivity was assessed by milk yield for 305 days of lactation using control milking once a month; suitability of cows for machine milking; reproductive functions of cows. Coefficients of correlation between economically useful traits and the share of genotype influence were calculated.

\section{Results and Discussion}

The farm uses Holsteinized Black Pied cattle with a proportion of Holstein blood (more than $75 \%$ ) and purebred Holstein animals of foreign breeding.

Table 1 shows the performance indicators of both breeds of cows.

Table 1. Productive qualities of cows of different breeds.

\begin{tabular}{|l|c|c|}
\hline & $\begin{array}{c}\text { Black-and-white } \\
\text { breed }\end{array}$ & Holstein breed \\
\hline Milk yield for 305 days of lactation, kg & $5958 \pm 112,32$ & $7022 \pm 98,67$ \\
\hline Fat content in milk, \% & $3,98 \pm 0,003$ & $3,92 \pm 0,002$ \\
\hline Protein content in milk, \% & $3,46 \pm 0,002$ & $3,24 \pm 0,001$ \\
\hline
\end{tabular}

Significant differences in that purebred Holstein cows differ from animals of Black Pied breed in milk yield per lactation by $1064 \mathrm{~kg}$ or $15.2 \%$ ( $\mathrm{P} \leq 0.01$, in favor of Holstein cows). In terms of quality indicators of milk - the content of fat and protein in milk, the superiority remained with Black Pied cows. The difference was significant at $\mathrm{P} \leq 0.05$ for fat content in milk and at $\mathrm{P} \leq 0.001$ for protein content. Both groups of cows exceeded the breed standard for milk yield per lactation, mass fraction of fat and mass fraction of protein in milk.

We carried out an eye assessment of the udder, which showed that all the cows used on the farm had the desired udder shape, that is cup-shaped and round. More than $60.0 \%$ of them have a bowl-shaped udder. Despite this, the breeds significantly differ in morphological and functional properties of the udder, particularly in suitability for machine milking (Figure 1). 


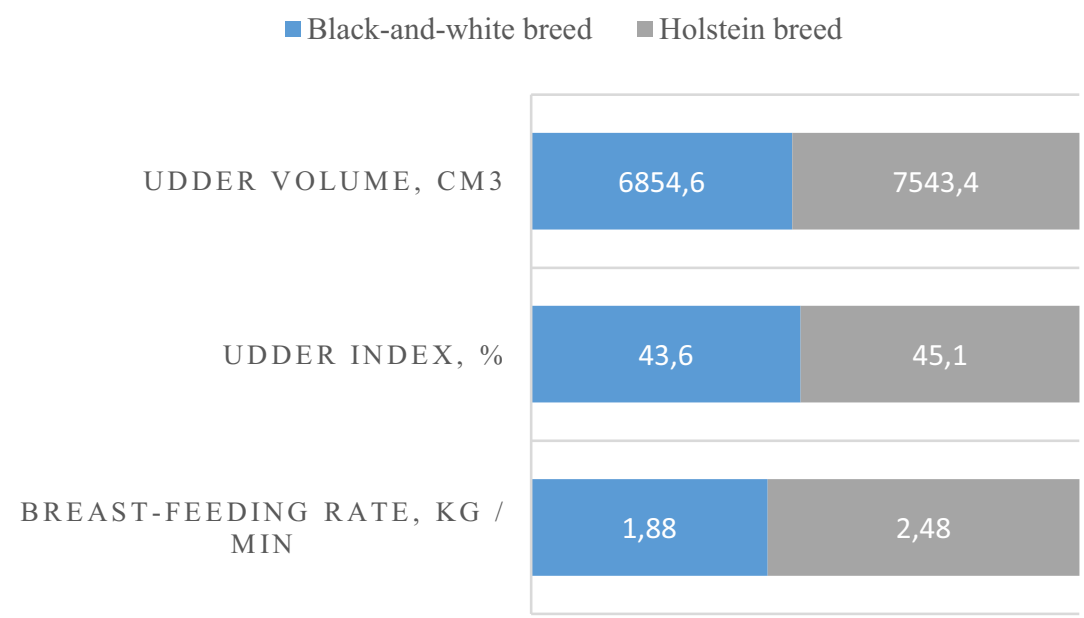

Fig. 1. Morpho-functional properties of the udder.

The figure clearly shows that according to all the studied indicators of the suitability of the udder for machine milking, cows of both breeds have rather high indicators, but the priority remains with animals of the Holstein breed of foreign selection. In terms of milking intensity and udder volume, they reliably surpass Black Pied cows at $\mathrm{P} \leq 0.05-\mathrm{P} \leq 0.01$, respectively, in terms of indicators. Holstein cows were also the best in the udder index. Their udder index was more than $45 \%$, which indicates the same development of the front and rear lobes of the udder. The difference between the breeds for this indicator turned out to be insignificant $(\mathrm{P} \geq 0.05)$.

The calculation of the correlation coefficients between economically useful traits showed that they are consistent with the physiological laws of milk formation and the assessment of the suitability of cows for machine milking (Figure 2).

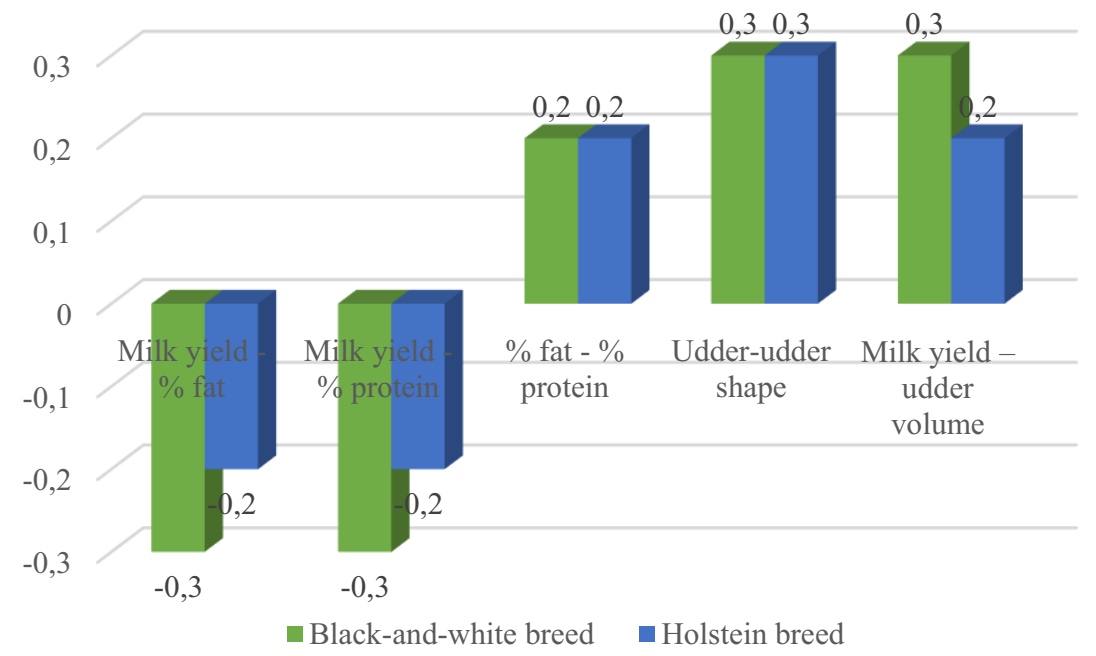

Fig. 2. Indicators of milk productivity. 
The correlation coefficients between the productive qualities, as well as between the quantitative indicator of productivity and the qualitative indicators of the suitability of cows for machine milking, were the same or did not differ significantly. In cows of the Russian Black Pied breed, they were slightly higher than in purebred Holstein cattle of foreign breeding; we associate this with the greater homozygosity of these animals.

Significant differences in and in reproductive functions were established (Figure 3).

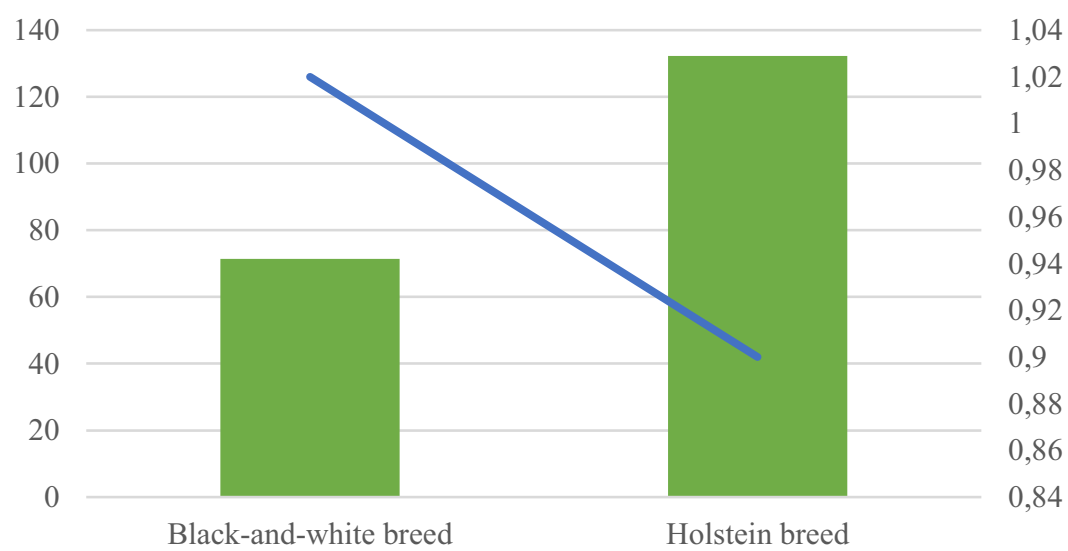

Duration of the service period, days $\longrightarrow$ of the FAC

Fig. 3. Indicators of the reproductive function of cows of different breeds.

As a result of the studies, it was found that purebred animals of Holstein breed of foreign selection have lower indicators of reproductive function, which is determined by a longer period between calving and fruitful insemination - the service period $(\mathrm{P} \leq 0.01)$ and a low coefficient of reproductive capacity - less than one. A positive correlation has been established between milk yield and the duration of the service period from 0.1 to 0.05 , depending on the breed, that is, an increase in its duration can lead to an increase in milk yield per lactation.

The calculation of the share of the influence of the genotype on a particular economically productive trait showed that the breed influences the productive qualities of cows, especially in purebred Holstein cattle of foreign breeding (Figure 4). 


\section{Proportion of the influence of the breed, \%}

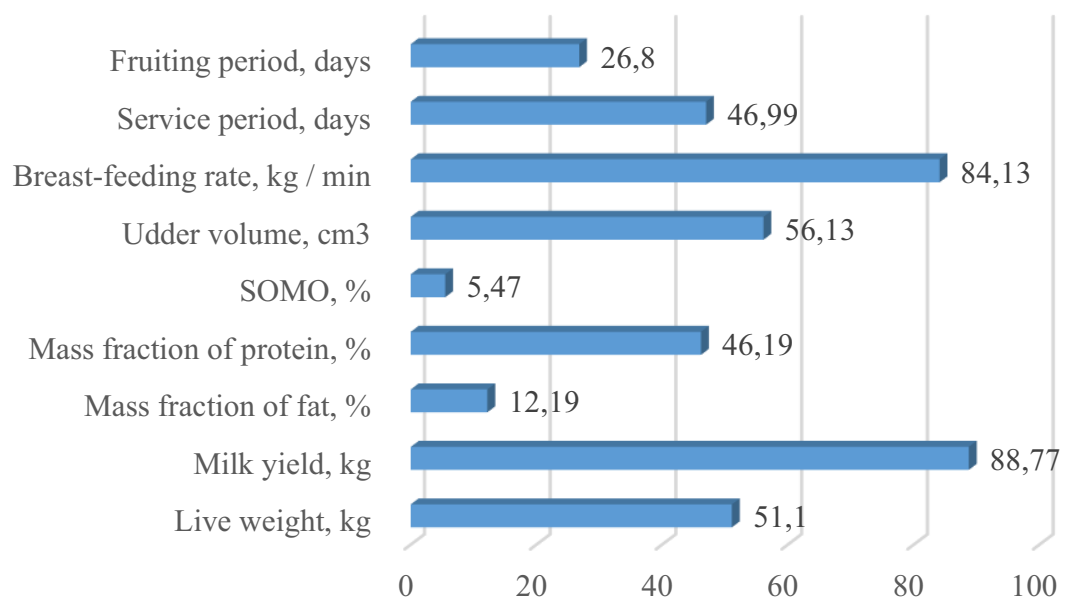

Fig. 4. The share of the influence of the breed in Holstein cattle on the productive qualities, \%.

The figure clearly shows that in Holstein cows of foreign breeding, the share of the influence of the genotype on their productive qualities is significant, which is determined primarily by the method of their breeding through long-term selection and selection and homozygosity for the main traits.

Similar data were obtained in the results of research by N.V. Bogolyubova, V.P. Korotky, A.S. Zenkin, V.A. Ryzhov, N.P. Buryakov [23,24], V. Mymrin and O.G. Loretts [21], O.V. Gorelik, O.E. Lihodeevskaya, N.N. Zezin, M.Ya. Sevostyanov and O.I. Leshonok [25-26].

\section{Conclusion}

Based on the above stated, it can be concluded that Holstein cattle of foreign breeding adapt well in an extreme continental climate, as evidenced by their high productivity.

\section{References}

1. O. Gorelik, M. Rebezov, A. Gorelik, S. Harlap, I. Dolmatova, T. Zaitseva, N. Maksimuk, N. Fedoseeva, N. Novikova, International Journal of Innovative Technology and Exploring Engineering 8(7), 559-62 (2019)

2. O. Gorelik et al., International Journal of Pharmaceutical Research (2019) Doi: 10.31838/ijpr/2019.11.01.133

3. O. Gorelik et al., Annual Research \& Review in Biology 18(4), 1-5 (2017) DOI: 10.9734/ARRB/2017/36937

4. A. Belookov, O. Belookova, V. Zhuravel, S. Gritsenko, I. Bobyleva, E. Ermolova, S. Ermolov, Y. Matrosova, M. Rebezov, E. Ponomarev, International Journal of Engineering and Advanced Technology 8(4), 1058-61 (2019)

5. F. Khaziakhmetov et al., Research Journal of Pharmaceutical, Biological and Chemical Sciences 9(3), 866-70 (2018) WOS:000438847100113 
6. F. Khaziakhmetov, A. Khabirov, M. Rebezov, A. Basharov, I. Ziangulov, E. Okuskhanova, International Journal of Veterinary Science 7(4), 178-81 (2018)

7. A. Gorelik et al., Advances in Agricultural and Biological Sciences 2(1), 5-12 (2016)

8. O.V. Gorelik et al., Advances in Agricultural and Biological Sciences 2(1), 27-33 (2016)

9. F. Smolnikova, Z. Moldabayeva, M. Klychkova, O. Gorelik, R. Khaybrakhmanov, I. Mironova, A. Kalimullin, G. Latypova, International Journal of Innovative Technology and Exploring Engineering 8 (7), 670-72 (2019)

10. N. Chernopolskaya, N. Gavrilova, M. Rebezov, S. Harlap, A. Nigmatyanov, G. Peshcherov, T. Bychkova, K. Vlasova, I. Karapetyan, International Journal of Pharmaceutical Research 11(1), 545-50 (2019) DOI: 10.35940/ijrte.B3158.078219

11. N. Chernopolskaya, N. Gavrilova, M. Rebezov, I. Dolmatova, T. Zaitseva, Y. Somova, M. Babaeva, E. Ponomarev, O. Voskanyan, International Journal of Engineering and Advanced Technology 8(4), 40-45(2019) DOI: 10.35940/ijrte.B3158.078219

12. N. Gavrilova, N. Chernopolskaya, M. Rebezov, D. Moisejkina, I. Dolmatova, I. Mironova, G. Peshcherov, O. Gorelik, M. Derkho, International Journal of Recent Technology and Engineering 8(2,) 2718-22 (2019) DOI: 10.35940/ijrte.B3158.078219

13. N. Gavrilova, N. Chernopolskaya, M. Rebezov, E. Shchetinina, I. Suyazova, S. Safronov, V. Ivanova, E. Sultanova, Journal of Critical Reviews 7(4), 233-36 (2020) DOI: $10.31838 /$ jcr.07.04.43

14. M. Temerbayeva et al., Annual Research \& Review in Biology 23(6), 1-7 (2018) DOI: $10.9734 / \mathrm{arrb} / 2018 / 38800$

15. M. Temerbayeva et al., Research journal of pharmaceutical biological and chemical sciences 9 (1), 291-95 (2018)

16. A. Serikova, F. Smolnikova, M. Rebezov, E. Okuskhanova, M. Temerbayeva, O. Gorelik, S. Kharlap, Sh. Baitukenova, S. Baitukenova, Y. Tumbasova, Research Journal of Pharmaceutical, Biological and Chemical Sciences 9(4), 495-500 (2018) WOS:000438848100062

17. F. Smolnikova, S. Toleubekova, M. Temerbayeva, E. Cherkasova, O. Gorelik, S. Kharlap, M. Derkho, M. Rebezov, I. Penkova, Journal of Pharmaceutical, Biological and Chemical Sciences 9(3), 1003-08 (2018) WOS:000438847100131

18. N. Kuramshina, M. Rebezov, E. Kuramshin, L. Tretyak, G. Topuria, D. Kulikov, A. Evtushenko, S. Harlap, E. Okuskhanova, International Journal of Pharmaceutical Research 11(1), 1301-05 (2019) DOI: 10.21668/health.risk/2019.2.04.eng

19. E. Skvortsov, O. Bykova, V. Mymrin, E. Skvortsova, O. Neverova, V. Nabokov and V. Kosilov, The Turkish Online Journal of Design Art and Communication 8(SMRCHSPCL) 291-99

20. V. Mymrin, O. Loretts, Contemporary trends in the formation of economicallybeneficial qualities in productive animals. Digital agriculture - development strategy Proceedings of the International Scientific and Practical Conference(ISPC 2019) Advances in Intelligent Systems Research 511-514 (2019)

21. S. Gridina, V. Gridin, O. Leshonok, Advances in Engineering Research, 253-256 (2018)

22. N. Bogolyubova, V. Korotky, A. Zenkin, V. Ryzhov, N. Buryakov, OnLine Journal of Biological Sciences 17(2), 121-27 (2017)

23. N. Bogolyubova, V. Romanov, V. Korotky, V. Ryzhov, A. Zenkin, Asian Journal of 
Pharmaceutical and Clinical Research 10(10), 117-20 (2017)

24. O.V. Gorelik et al., IOP Conf. Ser.: Earth Environ. Sci. 548, 082009 (2020) doi:10.1088/1755-1315/548/8/082009

25. O.V. Gorelik et al., IOP Conf. Ser.: Earth Environ. Sci. (2020) /10.1088/1755$1315 / 548 / 8 / 082013$

26. O. Gorelik et al., AIP Conference Proceedings 2207020012 (2020) doi $10.1063 / 5.0000317$

27. Z.S. Sanova, Agrarian Bulletin of the Urals, 01(204), 60-69 (2021) DOI: 10.32417/1997-4868-2021-204-01-60-69 (In Russian) 